\title{
ACUTE CENTRAL NERVOUS SYSTEM INFECTION BY TRYPANOSOMA CRUZI A ND AIDS
}

\author{
PASQUALE GALLO* - OTHELLO M. FABIÃO NETO* \\ JUAN M. MIRA SUAREZ * - ROVER P. BORBA *
}

SUMMARY - The acute infection of the CNS by Trypanosoma cruzi acquired by blood transfusion is uncommon. The concomitance of AIDS in the patient reported shows the importance of cellular immunity in restriction of this parasite, and reinforces the problem of blood transfusion in endemic zones.

KEY WORI>S: Chagas disease, AIDS, CNS infection.

Infeogão aguda do sistema nervoso central por Trypanosoma cruzi e AIDS

RESUMO - A infecção aguda do SNC pelo Trypanosoma cruzi por transfusão sanguínea é incomum. A concomitância da SIDA no paciente estudado mostra «a importância da imunidade celular na restrição deste parasita e alerta ao problema da transfusão sanguínea nas zonas endêmicas.

PALAVRAS-CHAVE: Doença de Chagas, AIDS (SIDA), infecção do SNC.

American trypanosomiasis (Chagas' disease) is a zoonosis caused by Trypanosoma cruzi. This flagellate protozoan is transmitted to human by hematophagous triatomine insects, through blood transfusion, and by congenital transmission. The risk of infection through blood transfusion has increased because of infected immigrants living in non-endemic areas ${ }^{4}$.

The acute central nervous system (CNS) involvement as a meningoencephalitis form, even rare, is frequently fatal $1.2,5,6$. We report a patient with acute CNS infection associated with AIDS.

\section{CASE REPORT}

VHF (Hospital Cristo Redentor 036315/24), a 26-year-old female from an urban area of Porto Alegre, ten days before her admission to the hospital started presenting some generalized myalgias, fever and asthenia, associated with conjunctival hyperemia. During the last two days, she progressively developed decreasing of visual acuity associated with left hemiparesls, and lapsed in coma. In the last five years she underwent a colicystectomy and three reoperations because of biliar tract infection, needing blood transfusion. She was stuporous and responsed to noxious stimuli, but not to verbal commands. She had left hemiparesis and right third nerve paresis. Computed tomography (CT) showed a hypodense, thick walled, ring-enhancing lesion in the midbrain (Fig. 1). Laboratory findings were: hematocrit 37\%; ESR $106 \mathrm{~mm} / \mathrm{hr} ; 7,600$ per mm3 WBC (1\% eosinophils, 22\% lymphocytes, 70\% neutrophils, $7 \%$ monocytes); 150,000 platelets; serum anti-HIV tests (Western-blot included) were positive. Cerebrospinal fluid (CSF) studies showed: 5 cells per mm3 (lymphocytes); $96 \mathrm{mg} / \mathrm{dL}$ proteins; glucose and chloride normal; security (CSF antibodies) and certainty diagnosis (Fig. 1) of Trypanosoma cruzi infection were made. Electrocardiogram was normal. The patient was treated with benzonidazole. Death occurred two months after admission because of respiratory infection.

* Medicai Doctor.

Dr. Othello Moreira Fabião Neto - Av. Duque de Caxias 955/303-A - 90010 Porto Alegre RS Brasil. 

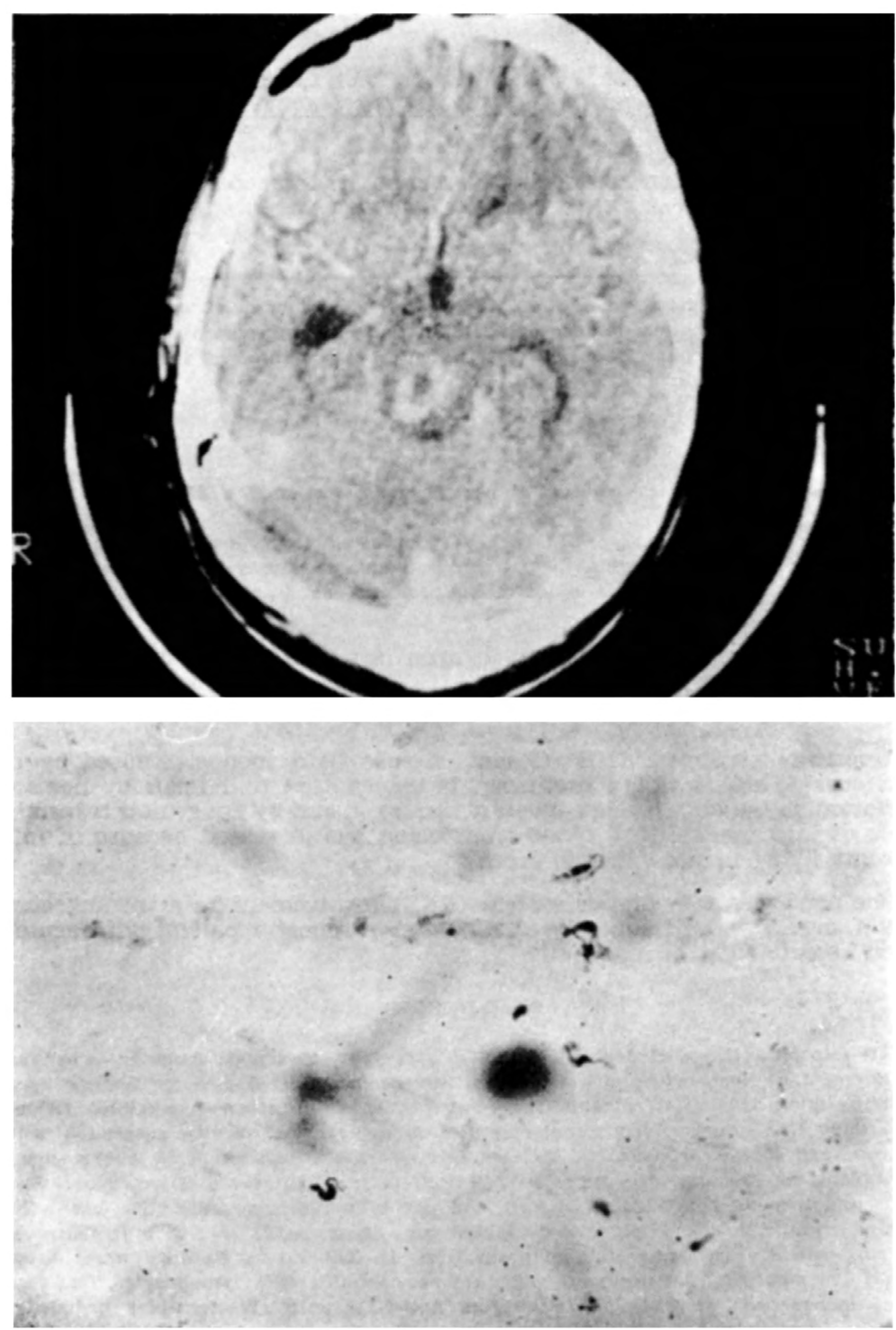

Fig. 1. Case VFH. Above: CT scan showing the lesion in the midbrain. Below: Trypanosoma cruzi in the $C S F$.

\section{COMMENTS}

American trypanosomiasis is an endemic disease in many regions of Latin America. In a recent study it has been estimated the prevalence rate of $4.9 \%$ for immigrants from Central America residents in the United States (equivalent from 
25,000 to 100,000 infected people). The estimated rate of infection is around $20 \%$ for the rural area of Argentina and El Salvador 3,4.

In endemic zones the transmission risk of the disease is a public health problem. The evaluated probability of acquiring Trypanosoma cruzi is around $22 \%$ for people who receive repeated transfusions in spite of the prophylactic measures 3 . The reported patient acquired Trypanosoma cruzi and the AIDS virus through blood transfusion. With the increasing number of immigrants into the United States coming from endemic zones, this kind of transmission became a risk in that country.

In 1916, Carlos Chagas separated the acute forms of this disease in two groups: benign cases, and the malign form which is commonly lethal (meningoencephalitis). The acute compromising of the CNS include meningoencephalitis with or without focal signs till a focal lesion with mass efect' $\subset$. Our patient developed a localized lesion at the midbrain. Meningoencephalitis generally shows necrotic charactheristics ${ }^{2}{ }^{4}$.

Diagnosis was confirmed through detection of Trypanosoma cruzi antibodies in the blood and in the CSF, and the certainty diagnosis through the detection of the parasite in the CSF by direct examination. In a previous article published by Spina-Franga et al. the security diagnosis (antibodies to Trypanosoma cruzi in CSF) was done although not the certainly diagnosis 9 . In chronic cases the certainty diagnosis is not expected, and only eventually the security one is don $\mathrm{e}^{1 \wedge}$

There are only eleven reported cases of acute infection of the CNS by Trypanosoma cruzi in immunocompromised hosts 6. Jorg et al. verified in lethal cases of acute meningoencephalits in children that the pathological liver exam constantly showed alterations similar to the African Kwashiorkor. This would be related to deficiency in the ability of developing immunity ${ }^{2}$. During chemotherapy for leukemia, whose cellular immunity is impaired, a reactivation of Chagas' disease can occur, as well as in AIDS. This evidences an important factor of the cellular immunity in the restriction of the parasite.5,7. With the increasing rates of infected pacients by HIV with neurological manifestations it is worth remembering the concomitant infection by Trypanosoma cruzi.

\section{R E F E R E N C E S}

1. Djalma J. Nota sobre el liquido cefalorraquídeo en la enfermedad de Chagas. An Inot Med Reg 1954, 4:47-55.

2. Jorg ME, Bustamante Ag, Peltier AY, Freire RS, Figueredo RC, Oliva R, Orlando AS. Disfuneion cerebral minima como secuela de meningoencefalitis aguda por Trypanoma cruzi. Prensa Med Argent 1972, 59:1658-1669.

3. Jost Lt. Turin M, Etchegoyen F, Leiguarda R, Taratuto AL», Iotti R. Meningoencefalitis chagasica en paciente con tratamiento inmunosupresor por transplante renal. Rev Neurol Arg 1977, 3:425-428.

4. Kirchnoff LV, Gam AA, Gilliam FC. American trypanosomiasis (Chagas disease) in Central American immigrants. Am J Med 1987, 82:915-920.

5. Kohl S, Pickering LK, Frankel LS, Yager RG. Reactivation of Chagas disease during thenapy of acute lymphocytic leukemia. Cancer 1982, 50:827-828.

6. Leiguarda R, Roncoroni A, Taratuto AL, Jost L, Berthier M, Nogues M, Freilij H. Acute CNS infection by Trypanosoma cruzi (Chagas Disease) in immunosupressed patients. Neurology 1990, 40:850-851.

7. Madeira ED, Andrade AFB, Bunn-Moreno MM, Barcinski M. Antibody dependent cellular cytotoxicity in Trypanosoma cruzi: characterization of the effector cell from normal human blood. Infect Immun 1979, 25:34-38.

8. Schmunis GA. Chagas disease and blood transfusion. In Dood RY, Barker LF (eds) Infection, Immunity and Blood Transfusion. New York: Alan R. Liss, 1984, p 127-145.

9. Spina-França A, Livramento JA, Machado LR, Yasuda N. Anticorpos a Trypanosoma cruzi no líquido cefalorraqueano. Arq Neuro-Psiquiat (São Paulo) 1988, 46:374-378.

10. Spina-França A, Mattosinho-França LC. American trypanosomiasis (Chagas diasease). In Vinken PJ, Bruyn GW (eds): Handbook of Clinical Neurology, Vol 35 (Infections of the Nervous System, Part III). Amsterdam: North Holland, 1978, p 85-114. 